ADAMIK TAMÁS

\title{
SIMON MÁGUS ALAKJA A KERESZTÉNY HAGYOMÁNYBAN
}

Simon mágus alakjáról és tevékenységéről több keresztény forrás tudósít. Dolgozatom elsố részében ezeknek a dokumentumoknak Simon mágus életére és tanítására vonatkozó adatait ismertetem. A második részben megkísérlem tisztázni tanításainak forrásait, a harmadikban pedig arra a kérdésre kívánok válaszolni, hogy kapcsolatba hozhatók-e tanai a gnoszticizmussal, s ha igen, milyen mértékben. Dolgozatom módszertani alapja két tételen nyugszik: a) Simon mágusnak követói voltak, a Simoniani, akik megórizték, illetve tovább fejlesztették tanításait, s tôlük meg lehetett tudni, mit tanított. b) Hogy csak késôi, azaz 2. és 3. századi szerzők beszélnek részletesebben tanításairól, annak az az oka, hogy ebben az időszakban kezdik az ortodox keresztény tanokat elkülöníteni a hamis vagy eretnek tanoktól. Ez a folyamat majd a niceai zsinat tevékenységében éri el a tetôpontját.

1. Az elsố keresztény mú, amely részletesen tájékoztat Simon mágus tevékenységérôl, Az apostolok cselekedetei. Fülöp apostol szamáriai tevékenységével kapcsolatban ezt találjuk benne Simonról: „Élt a városban egy Simon nevú férfi, aki varázsló volt, és azzal ámította Szamária népét, hogy fontos személynek adta ki magát. A népnek apraja nagyja hallgatott rá. „Ó az Isten nagynak nevezett ereje!” - mondták. Csüggtek rajta, mert már jó ideje csalta ôket mesterkedéseivel. De amikor hittek Fülöpnek, aki Isten országáról és Jézus Krisztus nevérôl beszélt nekik, megkeresztelkedtek, férfiak és nők egyaránt. Maga Simon is hívő lett, megkeresztelkedett és Fülöphöz csatlakozott. A jelek és a nagy csodák láttán elámult"1 $(8,9-13)$. Az a kép, amely ebben a bekezdésben Simon mágusról kibontakozik, tipikusnak mondható. Simon pogány mágus volt, de Fülöp csodáinak hatására megtért és csatlakozott a keresztényekhez. E modell szerint sok pogány vált híres kereszténnyé, például Tertullianus, Lactantius, Augustinus. Simon azonban más úton haladt. Már Az apostolok cselekedetei utal a kereszténységtől való eltávolodására: „Amikor a Jeruzsálemben maradt apostolok meghallották, hogy Szamária elfogadta az Isten szavát, elküldték

${ }^{1}$ A Szentírás magyar fordítását az alábbi kiadás alapján közlöm: Biblia. Ószövetségi és újszövetségi Szentírás. Szent István Társulat, Budapest 1976. 
hozzájuk Pétert és Jánost. Amikor megérkeztek hozzájuk, imádkoztak értük, hogy szálljon le rájuk a Szentlélek. ... Rájuk tették hát kezüket, s erre megkapták a Szentlelket. Amikor Simon látta, hogy az apostolok kézrátétellel közvetítik a Szentlelket, pénzt ajánlott fel nekik: „Adjatok nekem is olyan hatalmat — mondta - , hogy akire csak ráteszem a kezem, megkapja a Szentlelket” (8, 14-19).

Ebben a leírásban Lukács fontos tényt közöl: Simon meg akarta vásárolni a lelki hatalmat Pétertől. E tényről kapta a nevét a „simónia”: „lelki vagy lelki dolgokkal összefüggő anyagi dolgok juttatása, vétele, velük való kereskedés anyagi javakért vagy elónyért". De miért akarta Simon megvásárolni, nem pedig kiérdemelni a lelki hatalmat? Nyilvánvalóan azért, mert Lukács szerint alkalmatlan volt arra, hogy saját életének érdemeiért megkapja azt. A folytatás is sugallja ezt az értelmezést: „Péter elutasította. »Vesszen el a pénzed veled együtt, mert azt hitted, hogy Isten ajándékát pénzen meg lehet venni. Semmi részed benne és semmi közöd hozzá, mert szíved nem tiszta az Isten előtt. Térj meg hát gonoszságodból, és kérd az Istent, hogy bocsássa meg szíved szándékát! Úgy látom, elöntött a keserú epe, és fogva tart a gonoszság.« »Könyörögjetek értem az Úrhoz« — kérte Simon — »hogy semmi se érjen abból, amit mondtatok «" $(8,20-24)$.

Péter tehát felháborodottan utasította vissza Simon kérését, és világosan kifejezésre juttatta, hogy a mágus képtelen az üdvösségre. Simon válasza viszont meghökkentő: Kéri Péteréket: imádkozzanak azért, hogy ne következzék be az, amit Péter mondott neki. Ahogyan a késóbbi keresztény hagyomány mutatja, kérése nem teljesült.

Témánk szempontjából három dolgot tartok fontosnak Az apostolok cselekedetei leírásból. a) Simon mágus jelentôs személynek tüntette fel magát Szamáriában, b) mágikus tevékenységével mindenkit megbabonázott hosszú ideig, c) és a népek azt hirdették róla: „Ó az Isten nagynak nevezett ereje!” — oũ $\dot{\eta} \kappa \alpha \lambda$ ou $\mu \varepsilon ́ v \eta \mu \varepsilon \gamma \alpha \dot{\lambda} \eta^{2}(8,10)$. Ezen állításokból G. Schille arra következtet, hogy Simon valamiféle mozgalmat indított Szamáriában ${ }^{3}$, s mozgalma egybeesett Fülöp apostol itteni tevékenységével. R. Pesch szerint Simon egyféle szinkrétikus vallást hirdetett Szamáriában ${ }^{4}$, Roloff pedig hangsúlyozza, hogy Simon veszélyes konkurenciát jelentett Fülöp számára ${ }^{5}$, mert már elótte terjesztette tanait, s ezeknek ugyanolyan súlya lehetett hallgatói előtt, mint a kereszténységnek. A modern biblikus kommentároknak eme véleményeiben annyi igazság biztosan van, hogy Simon nemcsak mágikus tevékenységet folytatott Szamáriában, hanem valamiféle tanítással is megfogta hallgatóit, ám ebből a tanításból Az apostolok cselekedetei csak annyit

${ }^{2} \mathrm{Az}$ Újszövetség görög szövegét ezen kiadás alapján közlöm: Novum Testamentum Graece et Latine. Utrumque textum cum apparatu critico imprimendum curavit Eberhard Nestle, novis curis elaboraverunt Erwin Nestle et Kurt Aland. Editio vicesimo secunda. Stuttgart 1969.

${ }^{3}$ G. Schille: Die Apostelgeschichte des Lukas. Berlin 1984.

${ }^{4}$ R. Pesch: Die Apostelgeschichte. Zürich 1986, 274.

${ }^{5}$ Roloff: Apostelgeschichte, 134. 
árul el, hogy Simon a nép szerint „Isten nagynak nevezett ereje volt”. ${ }^{\text {. Hogy milyen }}$ tan rejtőzik e tömör kijelentés mögött, arra nézve a későbbi keresztény hagyományból kaphatunk bizonyos támpontot, elsôsorban Iustinostól, Irenaeustól és Hippolytostól.

Iustinos mártír (kb. 100-165) Flavia Neapolisban, a korábbi Sichemben született Palesztinában. Szülei pogányok voltak, ő maga a filozófia iránt érdeklődött. Elôször sztoikus, majd peripatetikus, végül pedig pythagoreus lett, de ez sem elégítette ki. Ezután a platonizmus felé sodródott, s ennek közvetítésével jutott el a kereszténységhez. Ezen életrajzi tények azért fontosak számunkra, mert kitúnik belőlük, hogy jól ismerhette a Simon mágussal kapcsolatos zsidó hagyományt és a különböző filozófiai irányzatokat. A kereszténységet is filozófiai alapon szemlélte, ezért a Simon mágusra vonatkozó információit nem szabad lebecsülni. Simonról több helyütt is nyilatkozik. Megemlíti, hogy Gittónban, Szamáriában született, majd Claudius alatt Rómába ment, s ott különféle csodákat produkált. A szamáriaiak és a rómaiak istennek tekintették. Rómában szobrot állítottak neki ezzel a felirattal: Simoni deo sancto ${ }^{7}$. A kutatásban felmerült az a gondolat, hogy Iustinos a szobor esetében téved, mert Semo Sancus szabin istenség szobrának feliratát (Semoni Sanco Deo Fidio sacrum) nézte Simon szoborfeliratának ${ }^{8}$. Ez nem valószínú, mert Simon szobrát és feliratát más szerzők is említik; például Tertullianus szerint szobrának talapzatán Sancti Dei felirat állt (Apol. 13, 9), az apokrif Péter-akta ismeretlen szerzője szerint pedig a felirat szövege a következő volt: Simoni iuveni deo, ami a görög Simoni neooi theooi „Simonnak, az új istennek” felirat félrefordítása (10). J. N. Bremmer felhívja a figyelmet arra, hogy Gaius Caesar és Germanicus is megkapta ezt a címet ${ }^{9}$. Ezután így folytatja Iustinos: „Majdnem minden szamáriai, sốt néhány más nemzetből való is a legfóbb istenként imádta ôt; egy bizonyos Helénát pedig, aki vándorlásaiban társa volt, annakelőtte pedig bordélyházi nó, úgy tisztelték, mint

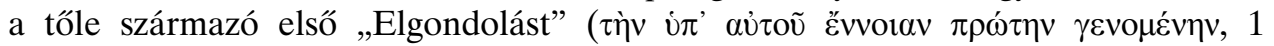
Apol. 26). A Párbeszéd a zsidó Tryphónnal címú múvében pedig megemlíti, hogy Simon mágust „minden eredet, hatalom és felsóbbség feletti istennek” mondták (120, $6)$.

Iustinos lényegében kifejti, hogy mit is takar Az apostolok cselekedeteinek „Isten nagy ereje” kifejezése. Simon a „legfőbb istennel” azonosította magát az (1. Apol.), s ugyanezt még nyomatékosabb kifejezésre juttatja a Párbeszédben: „minden eredet, hatalom és felsőbbség feletti Isten”. Teljesen új elem viszont az az információ, hogy

${ }^{6}$ E témához l. még: G. Lüdemann: The Acts of the Apostles and the Beginnings of Simonian Gnosis. New Test. Stud. 33 (1978) 420—426; J. Duncan M. Derrett: Simon Magus (Act 8, 9-24). Zeitschrift für die neutestamentliche Wissenschaft 73 (1982) 52-68; M. Smith: The Account of Simon Magus in Acts 8. In: Studies in the Cult of Yahweh. Volume two. Leiden, New York, Köln 1996, 140-151.

${ }^{7}$ J. C. Th. v. Otto: Iustini Philosophi et Martyris Opera. Jenae 1876, Tom. I. Pars I.

8 Vö. K. Beyschlag: Simon Magus und die christliche Gnosis. Tübingen 1974, 11.

${ }^{9}$ Vö. J. N. Bremmer: Aspects of the Acts of Peter: Women, Magic, Place and Date. In: The Apocryphal Acts of Peter. J. N. Bremmer (ed.). Leuven 1998, 10. 
vándorlásainak társnőjét, a prostituált Helenét „első ennoiájának”, elgondolásának nevezi. Hogy ez utóbbi kijelentés mit jelent, azt Irenaeustól tudjuk meg.

Irenaeus (kb. 130-202) Kis-Ázsiában született, 1778-tól Lugdunum püspöke, ezért feltételezhetjük róla, hogy jól ismerte mind a keleti, mind a nyugati gondolkodást. A közfelfogás az első rendszeres keresztény teológusnak tartja. A gnosztikusok ellen írt fố múve, az Adversus haereses rövidebb görög részletektől eltekintve csak latin nyelven maradt fenn. Simon mágusról részletesen ír, s megállapításai új gondolatokkal gazdagítják a vele kapcsolatos ismereteinket. Először is véleményt mond $A z$ apostolok cselekedetei azon kitételéról, hogy Simon mágus felvette a keresztséget. Szerinte Simon csak névleg lett keresztény azzal a céllal, hogy elsajátítva a keresztény tanokat és megszerezve az apostolok hatalmát még nagyobb mágus lehessen (1, 23,1). Mágikus tevékenysége miatt mindenki csodálta, Rómában is sikereket ért el: Claudius császár szobrot állíttatott neki. A zsidók között Fiúnak (Filius), Szamáriában Atyának (Pater), más népek előtt pedig a Szentléleknek (Spiritus Sanctus) nevezte magát. A legfelsőbb hatalmat (sublimissima virtus) vindikálta magának $(1,23,1)$.

Ezután Irenaeus kijelenti, hogy Simon, aki minden eretnekség kútfeje volt (ex quo universae haereses substituerunt 1, 23, 2), a következôt tanította (habet huiusmodi sectae materiam). Helénát, egy tyrusi bordélyházból való utcalányt, értelme elsô koncepciójának nevezte: primam mentis Conceptionem $(1,23,2)$. Heléna mindennek az anyja, mert Simon általa teremtette meg az angyalokat és az arkangyalokat. Heléna, az ô ennoiája mindent megismert, amiról az atyja azt akarta, hogy megismerje. Leszállt az alsóbb világokba és létrehozta az Angyalokat és a Hatalmasságokat, akik ezt a világot alkották. Miután létrehozta ôket, azok irigységből nem engedték el, és nem vettek tudomást róla, azaz Simonról, a legfőbb Istenrôl. Heléna szenvedett tôlük, mert nem engedték meg neki, hogy visszatérjen atyjához. Emberi testbe zárták. Így évszázadról évszázadra női testbe vándorolt, edényből edénybe: de vase in vas. Ugyanez az ennoia rejtózött abban a Helénában, aki a trójai háborút okozta. Ez az örökös átköltözés szenvedést okozott neki. Hogy véget vessen e szenvedésnek, prostituálta magát egy bordélyházban: ô az elveszett bárány: hanc esse perditam ovem. ${ }^{10}$

Simon testet öltött, hogy megtalálja ôt és megszabadítsa, hogy üdvösséget hozzon a népnek önmaga megismerése által: hominibus autem salutem praestaret per suam agnitionem $(1,23,3)$. Az angyalok ugyanis rosszul kormányozzák a világot, mert a vezetô helyért versengenek egymással. Azért jött Simon a világba, testet öltve, hogy megjavítsa azt. Emberi formában jelent meg, az erók, a hatalmasságok és az angyalok alakját véve magára, hogy az embereknek mint ember jelenjék meg, bár nem ember volt, és szenvedni látszott Judeában, bár valójában nem szenvedett.

${ }^{10}$ Platónnál is szerepel az a motívum, hogy Helénának csak az árnyképe jutott el Trójába (Phaidros 243 a; Állam 586 c); de már Hérodotos is ismerte ezt a változatot: 2, 113-120. Vö. még K. Beyschlag: i. m. 14-15; 23-24-25; D. R. MacDonald: Intertextuality in Simon's „Redemption” of Helen the Whore: Homer, Heresiologists, and The Acts of Andrew. Society of Biblical Literature. Seminar Papers 29 (1990) $336-343$. 
A próféták jövendöléseiket a világot teremtô angyalok hatása alatt végezték, ezért nem szabad komolyan venni őket: meg kell szabadulni tanításaiktól, hiszen Simon hozza az üdvösséget, nem az ô jövendöléseik. Nem léteznek természettôl igazságos cselekedetek, hanem csak konvenciók vannak, amelyekkel az angyalok le akarják igázni az embereket. Ezért Simon azt ígéri, hogy lerombolja ezt a világot és megszabadítja a népet azok hatalma alól, akik ezt a világot teremtették: Quapropter et solvi mundum et liberari eos qui sunt eius ab imperio eorum qui mundum fecerunt repromisit $(1,23,3)$.

Miután Irenaeus kifejtette Simon tanítását, tömören felsorolja, milyenféle mágikus mesterkedéseket folytatott: bájital, elvarázslás, isteni erő fölidézése, álmokkal való manipulálás. Majd megjegyzi még, hogy Simon és Helena gyakran ábrázolták magukat Zeus és Athéné képeivel, végül pedig megállapítja, hogy Simonnak követói is voltak: Simoniani, a quibus falsi nominis scientia accepit initia $(1,23,4)-$ „Simon-követők, akikkel ez a hamisnevú tudomány (ti. a gnosis) kezdôdött.”

Iustinos értesüléseit Irenaeus új elemekkel gazdagította: a) A Heléna-mítosz egy teológiai rendszer fontos részévé válik ${ }^{11}$. b) Határozottan megjelenik a dualizmus az istenfogalomban: van a legfóbb isten, s tôle különböznek a Heléna koncepciója alapján alkotott angyalok, akik a világot teremtették ${ }^{12}$. Ók a világgal együtt rosszak. c) A próféták is eme rossz angyalok hatása alatt jövendöltek, ezért nem szabad figyelembe venni kijelentéseiket. d) Heléna azért prostituálta magát, hogy megszabaduljon az angyalok hatalma alól. e) Simon azért inkarnálódott, hogy egyrészt közremúködjék Heléna megszabadításában, másrészt saját maga megismerése által üdvözítse az embereket.

A Heléna-mítosz értelmezéséhez fontos szempontot találunk Hippolytosnál (kb. 170-236), aki római presbiterként szigorú felfogása miatt szembe került a római egyházzal, és szakadást idézett elő, amennyiben Kallistos pápa alatt (217-222) ellenpápává választották. Gazdag irodalmi munkásságából kevés maradt ránk. Közöttük témánk szempontjából igen fontos a Refutatio omnium haeresium címú munkája. E múvében többször idéz egy Megalé Apophasis (A nagy kinyilatkoztatás) címú munkából, amelyet Simon mágus múvének tekint. Újabban azonban Simon szerzőségét megkérdőjelezik, és e múvet későbbi követőinek tulajdonítják ${ }^{13}$. Az egyik idézete így hangzik: „Az összes aiónoknak két fajtája van. ... Az egyik fajta a magasban

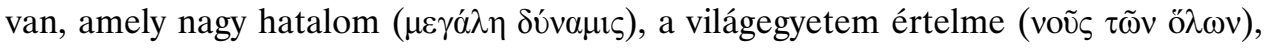
ez mindent irányít és hímnemú; a másik, amely lent van, a nagy eszme (غ̇лívor $\mu \varepsilon \gamma \alpha \dot{\lambda} \eta)$ nônemú, és minden dolgot létrehoz. Belül van az Atya, aki fenntart minden

${ }^{11}$ Lehetséges, hogy Goethe Faustjába Heléna a Simon mágus legenda alapján került; vö. Goethe: Faust. A tragédia második része. Magyar Helikon, Budapest 1961, 220-306; ford. Csorba Győző. Gy. Moravcsik: Zur Quellenfrage der Helenaepisode in Goethes Faust. In: Studia Byzantina. Budapest 1967, $428-438$.

${ }^{12}$ Talán ezért mondja Tertullianus, hogy Simon az angyaloknak szolgált: De praescript. haeret. 33.

${ }^{13}$ Vö. J. M. A. Salles-Dabadie: Recherches sur Simon le Mage. I. L' „Apophasis megalé'. Paris 1969. 
dolgot. ... Ez az, aki áll, aki állt és állni fog, lévén hím és nő egyszerre (oṽ̃ó

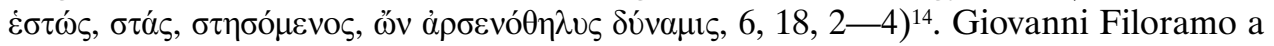
következô megjegyzést fúzi e hely értelmezéséhez: „A préexistens elv létrehoz egy létezőt mint önmaga képét, amely egyszerre férfinő. A férfi dimenziója szerint ez a létezó az értelem vagy intellektus, amely mindent irányít; a női dimenzió szerint ez a létező a gondolat, amelynek feladata a szülés. Így itt azon funkciók megkettőzésével találkozunk, amelyeket Irenaeus Simon-követői az Ennoiának tulajdonítottak: az Atya saját misztériumára vonatkozó kognitív erejével és a világ felé irányuló teremtő erôvel. E funkciók együttese helyreállítja az Atya tökéletes képét, akinek direkt szándéka, hogy megmentse a teremtett világot és az Embert. Ez a létezô, amely áll, állt és állni fog, ideális modellt szolgáltat a tökéletes gnosztikus számára"15. A fejlődésnek ezen szakaszában, amely a Megalé Apophasisban tükröződik, ez a tanítás már elválik Simon alakjától, ezért egyetérthetünk Filoramóval, amikor ezt írja: „E generáció Simon-követôje lemondva arról a szimbolizmusról, amely az Ennoia-Helénamítosz mögött rejtőzik, optimisztikusabban és egyetemesebben szemléli a gnosztikus mítosz lényegét: az önmagával való találkozást mint kísérletet, hogy helyreállítsa az eredeti androgynos egységet” ${ }^{\prime 6}$.

Az apostolok cselekedetei, Iustinos, Irenaeus és Hippolytos az eretnekségek kezdeményezőjét látják Simon mágusban és jól körülhatárolható tanítást tulajdonítanak neki. Kérdés, hogy ugyanezen idôből, azaz a Kr. u. 2-3. századból léteznek-e egyéb források, amelyek Simon tanairól tudósítanak. Léteznek ilyen források, mégpedig az apokrif iratok között. Péter aktájának ránk maradt részében Simon mágus és Péter apostol küzdelmét mutatja be. Simon Rómába jön, és az éppen gyökeret verô kereszténységet el akarja pusztítani, ezért a keresztények kétségbeesetten Rómába hívják Pétert, hogy vegye fel vele a harcot. Bár az irat Simon varázstevékenységére koncentrál, mégis Simon utolsó mutatványával kapcsolatban utal Simon tanítására is. Simon, aki halottfeltámasztás versenyében vereséget szenved Péterrel szemben, ezt mondja az ôt fenyegetô római népnek: „Én mindenesetre holnap elhagylak benneteket, ha már istentelenségetek és hitetlenségetek ilyen határtalan, felszárnyalok ahhoz az istenhez, akinek még most, gyengélkedve is az ereje vagyok. Ti elbuktatok ugyan, de lám, én maradok a „Helytálló”. Odamegyek majd atyám elé és tudatom vele: „Engem, a Helytállót, a fiadat is igyekeztek elgáncsolni, csakhogy én nem dől-

14 Vö. P. Wendland: Hippolytus Werke III: Refutatio omnium haeresium. Leipzig 1916, 144.

${ }^{15}$ G. Filoramo: A History of Gnosticism. Ford. A. Alcock. Cambridge, Mass. 1994, 150.

${ }^{16}$ G. Filoramo: i.m. 151. Az ellentétek egységét Weöres Sándor így önti formába Simon mágus címú versében: „Az Alkotó, meg a Romboló / nem léptek harcba sohasem: / köztük, a két örök-egy között / összjáték áll, nem küzdelem, / s a két szerető is délibáb csak, / a valóság: az egy-szerelem. In: Egybegyújtött írások. Budapest 1970, I 95. Ezt a kettősséget érezte meg a teremtó múvészben Márai Sándor, amikor ezt írta: „A múvészek mozdulatai azért olyan lágyak, kissé nóiesek, mert a múvész, az ősnemző, aki egyszerre termékenyító és kihordó, a vegyesnemú minden mozdulatában óriz valamit mesterségének üteméből, s ez az ütem mindig zenei, akkor is, ha ír vagy fest, vagy márvánnyal viaskodik a múvész" (Jelvény és jelentés. Utóhang. Sereghajtók. A Garrenek múve regényciklus harmadik része. Helikon Kiadó, Budapest 1996, 78). 
tem be nekik. Felemelkedtem önmagamhoz!” $(31)^{17}$. Itt tehát egyfelól az isten erejének mondja magát, másfelől magának az istennek, ,aki helytálló”. Ugyanazon görög formulának csak az elsố tagját alkalmazza itt, amely a Megalé Apophasisban fentebb teljes formában szerepelt. 18 Amikor pedig utolsó repüléséből Péter leimádkozza a földre, és Simon csontjait törve lezuhan a magasból, egyik barátja megjegyzi: „Ej, Simon, ha az «isten ereje» a lábát töri, nem fog-e üres árnyékképpé foszlani az az isten is, akinek te az ereje vagy?!" (32) ${ }^{19}$.

De szerepel Simon mágus a Pál-aktában is, amely töredékesen maradt ránk. Található a fennmaradt részben két levél. Az egyik $A$ korinthosiak levele Pálhoz, a másik Pál levele a korinthosiakhoz a testról. Az elóbbiben a korinthosi keresztények levelet írnak Pálhoz, s tudatják vele, hogy egy bizonyos Simon s Kleobios Korinthosba érkeztek és tanításaikkal megzavarják az itteni keresztények életét. Ezután tömören összegezik veszélyes tanaikat: „Nem kell használni - úgy vélik — a prófétai írásokat. Isten nem mindenható, a test feltámadása nem létezik, az ember teremtése sem Isten múve, nem igaz, hogy az Úr testet öltött, vagy hogy Máriától született, $\mathrm{s}$ a világ nem Istené, hanem az angyaloké" ${ }^{20}$. Pál válaszlevelében részletesen megcáfolja e tanokat. Bár a Pál-akta nem mondja, hogy ez a bizonyos Simon Simon mágussal azonos, az idézett tanításokból egyértelmú, hogy róla van szó, mert e tanítások jó része megegyezik azokkal, amelyeket Irenaeus Simonnak tulajdonít. Ezt egyébként megerősíti Eusebios is, aki Egyháztörténetében így ír: „ezekből származott Simon, akitől a simoniánusok, Kleobios, akitől a kleobianusok ... származnak” $(4,22,5)^{21}$. Eusebios egyébként jól ismerte Simon tanításait: ezeknek külön fejezetet szentel említett múvében $(2,13)$, amelyben ô is kijelenti, hogy Simon mindenféle eretnekség kezdeményezője volt.

Végül a források közül megemlítek még három múvet. Az Epistula apostolorum címú apokrif levél szintén a Kr. u. 2. század végén keletkezett. Ebben a feltámadt Krisztus apostolainak összefoglalja a kereszténység legfőbb tanait. Az ismeretlen szerző kijelenti, hogy „mindez Simon és Kerinthos miatt íródott” (12) ${ }^{22}$, mert ók az Úr ellenségei. A 3. századi kopt Péter-Apokalipszis e kijelentése: „,egyesek - mert az archonok hatalma alatt állnak — egy férfi nevét adják maguknak egy sok alakú és

${ }_{17}$ Az apostolok csodálatos cselekedetei. Szerk. Adamik T. Telosz Kiadó, Budapest 1996, 72. Ford. Szepessy T.

${ }^{18} \mathrm{~K}$. Beyschlag az Istenrôl mint állóról való spekulációt a zsidó hellénizmusból eredezteti, amelyet a későbbi korok Philóntól vettek át. Az Ószövetségben Istent gyakran ábrázolják állóként (Kiv 17, 6; 24, 10; M Törvény 5, 31): Jahve áll a Sínai hegyen. Ehhez járul a platóni állás (nyugalom) és mozgás (Timaios 57 e) és az Istenhez való hasonlóság tana (Theaitétos $176 \mathrm{a}-\mathrm{b}$ ): i.m. 45—47. Vö. még: P. F. Goedendorp: „If you are the standing one, I also will worship you" (Pseudo-Clementine Homilies II 24, 6). Proceedings of the First International Congress of the Société D'Études Samaritaines. Tel-Aviv University 1991, 61-77.

${ }^{19}$ Uo. 73. Ford. Szepessy T.

${ }^{20} \mathrm{Az}$ apostolok csodálatos cselekedetei 94. Fordította Tóth Klára.

${ }^{21}$ Euszebiosz: Egyháztörténete. Ford. Baán István. Szent István Társulat, Budapest 1983, 176.

${ }_{22}$ Epistula apostolorum. Etiópból fordította: Pesthy Mónika. In: Apokrif iratok. Levelek. Szerk. Adamik T. Telosz Kiadó, Budapest 1999, 58. 
sokat szenvedett mezítelen nóvel” egyes kutatók szent Simon mágusra, Helenára és követôire utal23 ${ }^{23}$ A szintén 3. században íródott Didaszkália címú munka is Simon mágust teszi meg az elsố eretneknek és hivatkozik néhány tanítására (XXIII. fejezet $)^{24}$

A fentiek alapján — úgy vélem — megállapíthatom, hogy a keresztény hagyomány szerint Simon mágus jól körvonalazható tanítással rendelkezett, s tanítását sikeres mágikus tevékenységével igyekezett hitelesíteni.

2. A kutatók egyetértenek abban, hogy Simon mágus valamiféle szinkretikus vallást hirdetett. Az apostolok cselekedetei, Iustinos és Irenaeus által neki tulajdonított tanítás valóban szinkrétikus jellegú, amelyben görög, zsidó és keresztény elemek egyaránt megragadhatók. Az anyag és a lélek dualizmusa ugyanúgy megfigyelhetô Platónnál (Törvények 896 e, Theaitétos 176 e), mint a teremtó isten bizonyos mértékú elválasztása a legfőbb istentól. A Timaiosban az ember testét nem a legfóbb Isten, hanem az „ifjú istenek”, az Isten gyermekei teremtik meg (42e). Hasonlóképpen Platónnál találkozunk azzal a gondolattal, hogy kezdetben kétnemú emberek is vol-

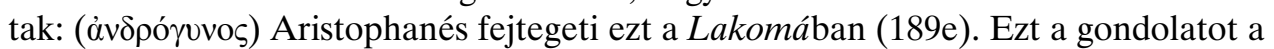
görög kultúrában jártas embernek könnyú volt átvinni az istenségre, hiszen a női istenségek a görög mitológiában és vallásban fontos szerepet játszottak. Hésiodos Theogoniájában a „szélesmellú Föld, mindennek biztos alapja — isteneké is” (117118), igen aktív: Úranos (154-160) és Kronosz (470) megbüntetésében fontos szerepet játszik. Szintén Hésiodostól tudjuk, hogy Zeus feleségeitől kapott bölcsességet és Igazságot. Első felesége, Métis: „istenek és a halandók közt legtöbb a tudása” (Theog. 887). Zeus lenyelte ốt, ,így jót és rosszat az istennô neki jelzi belülról” (Theog. 900). Második felesége Themis volt, s tôle vette Zeus a Törvényesség és a Jog ismeretét (Theog. 901-2).

Igaza lehet John Fergusonnak, aki hangsúlyozza, hogy a nói archetípus imádata mélyen bele van ágyazva az emberi természetbe. Az analitikus lélektan értelmezése szerint az ouroboros, a kígyó, amely önmaga farkába harap, a nagy kört szimbolizálja, amelyben hím és nő, pozitív és negatív, tudatalatti és tudatos elemek együttesen léteznek. Ebből az eredeti differenciálatlan szimbólumból kristályosodott ki a Nagy Anya, a Magna Mater és a Nagy Atya képe. Minden emberben ott szunnyad a férfiasság és nőiesség ereje (Jung animusnak és animának nevezi). Még a vadászok férfi uralta társadalmában is, a kőkorszakban, a nó imádatára koncentráltak. Az e korszakból fennmaradt mintegy hatvan szoborból 55 női szobor. A nô elementáris ereje kettôs: teremtő-átalakító és védő-tápláló. Ezzel magyarázható, hogy különbözô neveken, de szinte minden antik nép vallásában megvolt a Magna Mater kultusza ${ }^{25}$. A mezőgazdaság terjedésével ez a kultusz tovább erősödött Indiában, Mezopotámiában, Egyiptomban. A természet erejévé vált, az állatok úrnőjévé: Kybelé kocsiját

\footnotetext{
${ }^{23}$ I. Schneemelcher: New Testament Apocrypha. Westminster 1992, II, 706, 711. o. 24. jegyzet.

${ }^{24}$ Erdő P.: Az ókereszténykor egyházfegyelme. Ókeresztény Írók 5. Budapest 1983, $221-222$.

${ }^{25}$ J. Ferguson: The Religion of the Roman Empire. Ithaca, New York 1985 (1970) 13-16.
} 
oroszlánok húzzák és berkét oroszlánok őrzik. Bossuet talán nem alaptalanul hangsúlyozta, hogy a gnoszticizmus valójában a Magna Mater-kultusz volt, csak más néven, és több gnosztikus szektában a Szentlélek női principium volt ${ }^{26}$, $s$ ennek többek között az is oka volt, hogy a sémi nyelvekben a lélek szó nőnemú. Ezzel magyarázható az is, hogy a zsidó-keresztény hagyományban olykor a Szentlelket anyának értelmezték ${ }^{27}$. Nem lehet véletlen az sem, hogy Catullus, akinek költészetében a szerelem középponti szerepet játszik, a Magna Maternek is szentelt egy költeményt, s a Catullus-kutatásban is kapcsolatba hozták már a gnoszticizmussal ${ }^{28}$.

Efféle görög elképzelések közismertek lehettek Szamáriában, amelyet a makedónok a Kr. e. 4. században elfoglaltak és hellenizáltak. A hellénizmus hatására e területen is megnőtt az érdeklődés a misztériumvallások iránt. W. K. C. Guthrie feltételezi az orphizmus hatását is, például a jó pásztor alakját innen eredezteti: elóbb átvették a zsidók, majd tőlük a keresztények ${ }^{29}$. Egyébként már Hippolytus utalt Simon feltételezett görög forrásaira: Empedoklésre (6, 11-12), az Ószövetség és a homérosi eposzok allegorikus értelmezésére (6, 15-16), hangsúlyozva, hogy Simon ismerte a sztoikusok allegorikus módszerét. Hans Leisegang pedig részletesen foglalkozott a görög hatás kérdésével, s kiemelte, hogy Simon tanítása régebbi, mint az evangéliumoké, és a görög mitológia és filozófia nagy szerepet játszik benne ${ }^{30}$.

B. A. Pearson a zsidó hagyomány szempontjából foglalkozott a kérdéssel, mégpedig a Nag Hammadiban talált gnosztikus szövegek alapján. Az Igazság testimóniuma címú iratban az Ószövetség egyes részeivel foglalkozó midrások találhatók ${ }^{31}$. $\mathrm{Az}$ egyik a Genezis 3. fejezetének kígyóját értelmezi, s azt mondja róla, hogy „okosabb volt a Paradicsom minden állatánál”, a tanító szerepét töltötte be: Évát tanította, Éva pedig Ádámot. Az archonok természetérôl címú írás pedig azt fejtegeti, hogy »a lelki asszony« (az égi Éva, a Sophia) a kígyóba költözik, a tanítóba, aki a testi Ádámot és Évát tanítja. Hasonló gondolatmenetet talált $A$ világ eredetéról címú írásban. Ebben is szó van a tanítóról, akinek az anyját a héberek Éva-Zoénak, az Élet tanítójának hívják. Ez az értelmezés Pearson szerint zsidó forrásokból szárma$z^{32}{ }^{32}$. Pearson szerint ez a midrás azonosítja a tudás fáját a fügefával, $\mathrm{s}$ ez is zsidó hagyományt tükröz. Amikor Ádám elrejtőzik, és Isten kérdezi, hogy „Hol vagy Ádám?" Mire Ádám azt válaszolja, hogy a fügefához jött. Ekkor Isten megtudja,

${ }^{26}$ J. Ferguson: i. m. 31.

27 Vö. D. Vigne: Christ au Jourdain. Paris 1992, 205-232.

${ }_{28}$ Vö. B.-M. Näsström: The Abhorrence of Love. Göteborg 1989, 88-92.

${ }^{29}$ W. K. C. Guthrie: Orpheus and Greek Religion. London 1952, 264.

${ }^{30}$ H. Leisegang: Die Gnosis. Stuttgart 1985, 88-93; K. Rudolph szintén lehetségesnek tartja ezt: Die Gnosis. Göttingen 1994, 318: „Für den historischen Simon ist sicherlich anzunehmen, daß er in Samarien eine gnostische Gemeinde gründete, die von dem sich ausbreitenden Christentum als ernsthafte Konkurrenz betrachtet wurde ...”; Kákosy L.: Fény és káosz. Budapest 1984, 19: „Simon múködése részben a kereszténység előtti gnózishoz tartozik."

${ }^{31}$ B. A. Pearson: Jewish Haggadic Traditions in the Testimony of Truth from Nag Hammadi (C. G IX, 3), in: Ex orbe religionum. Studia Geo Widengren oblata I. Leiden 1972, 458.

${ }^{32}$ B. A. Pearson: i. m. 464. 
hogy Ádám evett a tiltott fa gyümölcséből. E midrás szerint Isten irigyli Ádámtól a tudás $\mathrm{t}^{33}$. Végül Pearson foglalkozik a gnosztikus Démiurgos alakjával, aki vak és bolond. E szöveg a Teremtô ostobaságát a Genezis 3,9 kérdésével bizonyítja: „Ádám, hol vagy?” A mindentudó Isten nem tudja, hogy hol van Ádám. A fenti szövegek alapján Pearson megállapítja, hogy a gnoszticizmusban fontos a lázadás motívuma, és ez a lázadás a zsidóságon belül keletkezett. Pearson szerint ez a fordulat a zsidóság esetében valamilyen történelmi krízis idején következhetett be. A zsidók számára ugyanis Isten hagyományosan a történelem és a teremtett világ ura volt. Nagy krízisnek kellett ahhoz bekövetkeznie, hogy e régi hagyományt újraértékeljék. E történelmi krízis és a vallási-kulturális szinkrétizmus fontos szerepet játszhatott e forradalmi változásban, azaz a gnoszticizmus csíráinak keletkezésében. Mikor és hol következett be ez a változás - teszi fel a kérdést Pearson. Véglegesen nem tudja ugyan megválaszolni, de azt gyanítja, hogy a Kr. e. 1. században Palesztinában és Szíriában ${ }^{34}$.

Pearson sejtése igaz lehet, mert a Kr. e. 1. században volt olyan krízishelyzet, amely egyes hellenizált zsidókban felébreszthette azt a gondolatot, hogy atyáik Istene nem mindenható. Ez a tragikus esemény - véleményem szerint - akkor következett be, amikor Pompeius véres harcok árán elfoglalta Jeruzsálemet Kr. e. 63ban $^{35}$. Aristobulos és Hyrkanos trónviszályába a zsidók bevonták Pompeiust, aki mivel a civakodó felek nem tudtak megegyezni, Jeruzsálem ellen vonult. Aristobulos hívei ellenálltak, ezért Pompeius ostromgépeket hozatott és három hónapi véres ostrom után elfoglalta a várost. Iosephus Flavius így festi le az ostromot: „Hogy pedig mennyire szívünkön viseljük Isten tiszteletét és a törvény megtartását, az már abból is kiderül, hogy a papokat még az ostrom alatt sem tartotta vissza a félelem az áldozatok bemutatásától, sőt napjában kétszer, reggel is és a kilencedik órában is elvégezték az oltári szolgálatot és egyetlenegyszer sem mulasztották el, akkor sem, ha az ostrom közben akármilyen súlyos esemény történt. Amikor a várost a harmadik hónap böjtnapján, a 179. Olympias évében, Gaius Antonius és Marcus Tullius Cicero konzulsága alatt bevették és a benyomuló ellenség mindenkit lekaszabolt, aki a templomban volt, a papok akkor sem zavartatták magukat az áldozatok bemutatásában, nem reszkettek az életükért, nem riasztotta vissza óket a rengeteg hulla, tehát nem menekültek, hanem inkább ott az oltárnál akarták elszenvedni az elkerülhetetlen halált, mintsem hogy a törvény bármelyik rendelkezését megszegjék.” ... „Erre általános mészárlás kezdődött: a zsidókat részben a rómaiak, részben a tulajdon honfitársaik aprították. Voltak, akik a mélységbe vetették magukat, mások felgyújtották házaikat és maguk is benn égtek, mert nem akarták elviselni azt, aminek be kellett következnie. Így mintegy tizenkétezer zsidó esett el, a rómaiakból viszont igen

\footnotetext{
${ }^{33}$ B. A. Pearson: i. m. 465.

${ }^{34}$ B. A. Pearson: i. m. 470 .

35 Vö. J. Hadot: Penchant mauvais et volonté libre dans le Sagesse de Ben Sira. Paris 1970, 17.
} 
kevesen" (Jos. Flav. A zsidók története 14, 4, 3-4) ${ }^{36}$. Hasonló politikai krízist okozott Heródes trónralépése. Róma segítségével lett Judea királya, amelyet három évi véres harc után tudott elfoglalni, s gyôzelme után szörnyú vérfürdőt rendezett, Kr. e. 37-ben ${ }^{37}$.

Pearson tehát a gnoszticizmus kezdeteit a Kr. e. 1. századra helyezi és a zsidóságnak tulajdonítja. Említésre méltó, hogy a 9. században egy szírül író keresztény szerző, Moses Bar Cepha $^{38}$ a teremtéstörténet szinte ugyanazon helyeinek gnosztikus értelmezését, amelyeket fentebb Pearson vizsgált, Simon mágusnak szájába adja. Például Simon mágus azt mondja, hogy az Ádámot teremtô Isten tehetetlen és gyenge volt, mert nem tudta elérni, hogy olyannak maradjon Ádám, amilyennek ő akarta. Azt is állítja Simon, hogy Isten irigységbő́l nem akarta azt, hogy Ádám a tudás fájáról egyen, továbbá Simon több Istent tételezett fel. Azt, aki Ádámot teremtette, gyöngének és irigynek tekintette, a másikat pedig az igazi, felsőbb rendú Istennek. E teremtó Istent tehát megvetette, éppen emiatt tagadta a testek feltámadását ${ }^{39}$. Ez utóbbi kijelentés azért figyelemre méltó, mert a feltámadás tagadása a Pál-aktából fentebb idézett Korinthosiak levele Pálhoz címú iratban is szerepel.

De az említett források szerint Jézus, vagyis a kereszténység tanai is alakíthatták Simon mágus tanítását. Egyértelmú belőlük, hogy Simon Jézussal rivalizált, ezért jelentett mindenütt veszélyt a kereszténységre. A kereszténység hatása mutatkozik meg abban például, hogy Irenaeus szerint a zsidók között Fiúnak, Szamáriában a Szentléleknek mondta magát. Jézus hatását láthatjuk abban, hogy bár Simon a legfóbb istenként lépett fel, olykor a fiúval azonosítja magát. Krisztushoz hasonlóan megtestesült, Judeában szenvedett, de csak látszólag. A Péter-aktában azt karja bizonyítani, hogy Jézus közönséges zsidó ács volt, s ő maga az igazi megváltó ${ }^{40}$.

3. Végül feltehetjük a kérdést, vannak-e gnosztikus vonások Simon mágus tanításában? A kérdést az teszi indokolttá, hogy amíg a korábbi kutatásban szinte egyöntetúen elfogadták a kereszténység előtti gnózis létezését, és Simon mágust is követői

${ }^{36}$ Josephus Flavius: A zsidók története. Görög eredetiból fordította Révay József. Gondolat-Talentum, Debrecen 1994, 190-191.

37 Vö. G. Fohrer: Geschichte Israels. 4. Auflage. Wiesbaden 1985, 228.

38 Moses Bar Cepha: De paradiso, Pars III caput I. In: Patrologia Graeca Tom. 111, 592-596; vö. még: Sasagu Arai: Simonianische Gnosis und die Exegese über die Seele. Gnosis and Gnoscitism. Papers read at the Seventh International Conference on Patristic Studies (Oxford, September 8th-13th 1975). Edited by M. Krause. Leiden 1977, 185-203.

39 Vö. Tertullianus: De praescriptione haereticorum 33,2: „Pál a korinthusiaknak írt első levelében (vö. 1 Kor 15,12) elítéli azokat, akik tagadják vagy kétségbe vonják a feltámadást. Ez a vélemény a szadduceusokra volt jellemző. Ebben követik óket Markion, Apellesz, Valentinus és mindazok, akik a test feltámadását ellenzik" (Tertullianus múvei. Szent István Társulat, Budapest 1986, 445; ford. Erdô Péter).

${ }^{40}$ Vö. Az apostolok csodálatos cselekedetei. Péter Rómában 14. Telosz Kiadó, Budapest, 1966, 55: „Én vagyok itt, Simon! Ezért hát gyere le, Péter, és én bebizonyítom, hogy egy szürke kis zsidó, egy ács fia, akiben hiszel". Ford. Szepessy T. 
közé sorolták ${ }^{41}$, addig az újabb kutatásban, amelyet Karlmann Beyschlag Simon Magus und die christliche Gnosis címú könyve képvisel a legmarkánsabban ${ }^{42}$, tagadják egy ilyen gnoszticizmus létét, $\mathrm{s}$ ha ez nem létezett, akkor Simon mágus tanításában sem lehettek gnosztikus elemek. Beyschlag arra alapozza elméletét, hogy Simon mágusról Az apostolok cselekedeteiben hallunk elôször, amely 100 körül keletkezett, tanairól pedig részletesebben csak újabb 50 év múlva Iustinos tudósít, majd még később Irenaeus, ezért Beyschlag feltételezi, hogy a neki tulajdonított tanok másodlagos fejlemény eredményei, tehát nincs közük a történeti Simon mágushoz.

Tulajdonképpen tetszetôs ez az elmélet, és a legújabb kutatásban többen elfogadják ${ }^{43}$. Ennek ellenére megkérdôjelezhetô, mert a gnózis mint a keresztény tanítástól elütô, azzal ellenkezô tan már Pál apostol leveleiben is fellelhetô, pedig ezek a levelek alkotják a kanonikus Újszövetség legkorábbi részeit, az 1. század 50-es éveitől ${ }^{44}$. Másfelól az a két tanítás, amely Simon mágus rendszerében fontos helyet foglalt el, a dualizmus az istenség eszméjében és a nôi principium mint teremtô elv mint láttuk -, már Simon mágus elótt jóval korábban megragadható a vallástörténetben és mitológiában, és a késôbbi gnoszticizmusban is jelentôs szerepet játszott. Nincs hát kényszerítő okunk arra, hogy feltételezzük: ezek a gondolatok nem fordulhattak elő Simon mágus tanításában, különösen akkor, ha Iustinos és Irenaeus kifejezetten állítják, hogy vallotta ezeket a tanokat. Irenaeus elemzéseinek alaposságát már Tertullianus hangsúlyozta ${ }^{45}$, de modern kiadói is kiemelik megbízhatóságát ${ }^{46}$.

${ }^{41}$ Vö. J. Quasten: Patrology. Vo. I. The Beginnings of Patristic Literature. Utrecht-Antwerp 1975 (1950) 254-255; H. Haag: Bibliai Lexikon. Budapest 1989, 495: gnózis; Komoróczy G.: Simon mágus. In: Világirodalmi Lexikon 13. Budapest 1992, 142; Smith's Bible Dictionary. New York 1985, 649: „According to ecclesiastical writers he was born at Gitton, a village of Samaria, and was probably educated at Alexandria in the tenets of the Gnostic school." Kákosy L.: i. m. 18-21; Hahn I.: A próféták forradalma. Vallástörténeti és történelmi tanulmányok. Budapest 1988, 87-102; 171-201; W. Foerster: Die „ersten Gnostiker" Simon und Menander. In: Le origini dello gnosticismo. Collquio di Messina 13-18 aprile 1966. Leiden 1967, 190-196.

${ }^{42}$ K. Beyschlag: i. m. 211-219. Vö. G. Schille: i. m. 208: „dieser selbst aber wirklich nur ein berühmter Magier, nicht ein gnostischer Sektenstifter”; R. Pesch: i. m. 174: „Simon ist also Vertreter einer synkretischer Religiosität, dürfte heute geklärt sein”.

${ }^{43}$ Vö. H. R. Drobner: Lehrbuch der Patrologie. Herder, Freiburg-Bazel-Wien 1994, 86: „Die Schriften von Nag Hammadi haben unsere Kenntnisse des Gnostizismus wesentlich erweitert und u. a. die Zuverlässigkeit des Irenäus bestätigt, wenn auch die fehlenden Originaldokumente immer unersetzlich bleiben. ... Jedenfalls ermöglichen auch sie keinerlei Rückschlüsse auf Entwicklungsstufen der Gnosis vor dem 2. Jh. Ihre Ursprünge liegen daher noch immer im dunkeln, und man kann nur soviel sicher sagen, dass sich in ihr das grundlegende Streben der vorchristlichen hellenistischen Welt nach Erkenntnis fortsetzt. Alle darüber hinausgehenden Erklärungsversuche aus griechischer Philosophie und Religion, Judentum, persischen Quellen, Neuem Testament u. a., wie sie vor allem von der religionsgeschichtlichen Schule um R. Reitzenstein und W. Bousset sowie von R. Bultmann und seiner Schule vertreten wurden, können nicht als gesichert gelten”; 87: „Die von den Kirchenvätern überlieferte Überzeugung, Simon Magus sei der erste Gnostiker gewesen, trifft keinesfalls zu".

${ }^{44}$ Már Tertullianus felhívja erre a figyelmet, vö. De praescriptione haereticorum 33, Adversus Valentinianos 5, 2. Vö. Ph. Vielhauer: Geschichte der urchristlichen Literatur. Berlin, New York 1975, 133, 195, 214, 226 sk., 234.

45 Tertullianus: Adversus Valentinianos 5, 1.

${ }^{46}$ Irénée de Lyon: Contre les Hérésies I, ed. A. Rousseau et L. Doutreleau. Paris 1979, 151-152. 
Azt hiszem, nem tévedek akkor, amikor a kereszténység előtti zsidó gnoszticizmus keletkezését ahhoz a kiábrándult korhoz kapcsolom, amely a zsidó apokalyptikát is megteremtette és az esszénusok elkülönüléséhez is lökést adott. Ez is a Kr. e. 2-1. századra utal. E társadalmi és politikai szituáció azonosságával magyarázható az a tény, hogy szembeötlő hasonlóságok vannak a gnoszticizmus, az apokalyptika és az esszénusok tanítása között. A gnoszticizmust és az apokalyptikát egyfajta pesszimizmus jellemzi, amely dualizmuson alapul. Az apokalipszisekben a korszakok, az aiónok dualizmusán: a jelen korszak ideiglenes és rossz, az eljövendő korszak viszont végleges és jón ${ }^{47}$. A gnoszticizmusban az istenség dualizmusán: a teremtố isten a rossz, a legfő́bb isten a jó. Ez a hasonlóság is hozzájárulhatott ahhoz, hogy több gnosztikus jellegú apokalipszis is keletkezett, például Ézsaiás próféta felemelkedése és Jakab apokalipszise. Ez a pesszimizmus az esszénusokról is elmondható. Nyilvánvalóan nem voltak megelégedve a hivatalos zsidó kultusszal, azért különültek el. A bibliai szövegek értelmezésében náluk is megfigyelhetô bizonyos dualizmus: példáikban a búnös és az igaz képviselőit állítják egymással szembe: a Gonosz Pap és az Igaz Tanító, a Fény Fiai és a Sötétség Fiai. Eszmeviláguk közel állt az apokalyptikához, például Hénok apokalipszisét ismerték és olvasták ${ }^{48}$.

J. Ferguson szerint Freud ismeretében a mi generációnk jobban meg tudja érteni a gnosztikusokat. Ők ugyanis Freudot megelôzve észrevették a vallás és a szexualitás közötti kapcsolatot, $\mathrm{s}$ a gnózist, a megismerést ugyanúgy két értelemben használták, mint a Biblia ${ }^{49}$. Egyébként a női principium fontosságának hangsúlyozása napjaink teológiai gondolkodásában is jelen van. Joseph Ratzinger bíboros korunk teológiai irányzatait elemezve a felszabadítás teológiájáról a következóket mondja: „Időközben a felszabadítás eszméje — amennyiben a szabadságot jelölhetjük meg az újkori gondolkodás és századunk közös nevezőjeként — nagyon erősen összeolvadt a feminista ideológiával is. Most a nő számít igazán elnyomott lénynek; ezért a nó fölszabadítása minden fölszabadítási törekvés középpontjában áll. Ezzel a politikai fölszabadítás-teológiát egy antropológiai változat tetézi, és nem csupán kényszerszerepektốl való megszabadításra gondolnak, hanem a végsô cél az ember biológiai meghatározottságtól való megszabadítása. ... Végsố soron a teremtett voltunk elleni lázadásról van szó. Az embernek — az önistenítés ôsi kísértésének modern változataként — Istenként önmaga teremtôjévé kell lennie" ${ }^{50}$ Majd kissé lejjebb így folytatja: „Latin-Amerikában, miután a marxista hullám lecsillapodott, nagyon erősen jelentkezik az elsüllyedt kultúrák fölfedezésének igénye. Az „indián teológia” újjá akarja éleszteni a Kolumbus előtti kultúrát és vallást, s meg akar szabadulni az idegen, ráeróltetett, európai elemektôl. Érdekes kapcsolódás mutatkozik a feminizmussal: hangsúlyozzák a földanya kultuszát és a nőiességet Istenben.”

47 W. Schneemelcher: Neutestamentliche Apokryphen. II. Band. Tübingen 1964, 412-413.

${ }^{48}$ Fröhlich Ida: A qumráni szövegek magyarul. Piliscsaba 1998, 27-35.

${ }^{49}$ J. Ferguson: i. m. $130-131$.

${ }^{50}$ Joseph Ratzinger bíboros: A föld sója. Kereszténység és Katolikus Egyház az ezredfordulón. Beszélgetés Peter Seewalddal. Szent István Társulat, Budapest 1997. 107-108. Ford. Diós I. 